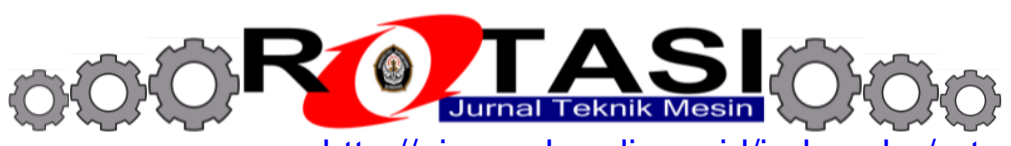

Available online at Website http://ejournal.undip.ac.id/index.php/rotasi

\title{
PERBANDINGAN PRODUK RODA GIGI UKM DAN RODA GIGI ORIGINAL EQUIPMENT MANUFACTURER (OEM) UNTUK PRODUK RODA GIGI TRANSMISI SEPEDA MOTOR
}

\author{
*Rifky Ismail \\ Jurusan Teknik Mesin, Fakultas Teknik, Universitas Diponegoro \\ Jl. Prof. Sudharto Kampus UNDIP Tembalang Semarang \\ *Email: $\underline{\text { r_ismail@undip.ac.id }}$
}

\begin{abstract}
ABSTRAK
Roda gigi merupakan salah satu komponen mesin yang kompleks dalam proses perancangan dan pembuatannya. Hingga saat ini, Usaha Kecil dan Menengah (UKM) produsen komponen otomotif di Jawa Tengah belum mempu memproduksi roda gigi untuk sistem transmisi sepeda motor yang mampu memenuh standar perusahaan otomotif nasional atau mampu menjadi komponen after sales di pasar komponen purna jual. Berdasarkan survey yang dilakukan di pasar purna jual di Semarang terhadap produk roda gigi transmisi sepeda motor, roda gigi transmisi yang dijual merupakan produk Original Equipment Manufacturer (OEM) atau produk impor dari China dan Taiwan. Berdasarkan survey di UKM, roda gigi yang diproduksi UKM lebih mengarah pada pesanan yang spesifik (customized) dan belum menjadi produk massal. Penelitian ini mencoba mendorong UKM untuk memproduksi roda gigi yang dapat diproduksi massal dan memberikan pesasanan secara kontinyu. UKM produsen roda gigi di Kecamatan Juwana, Kab. Pati, diberikan order pembuatan roda gigi untuk sistem transmisi sepeda motor. Produk roda gigi yang dihasilkan UKM ini kemudian dianalisa dan dibandingkan dengan produk roda gigi OEM. Hasil yang dibandingkan adalah uji komposisi, struktur mikro, nilai kekerasan dan kekasaran permukaan. Analisa perbandingan menunjukkan bahwa proses manufaktur roda gigi produk UKM hingga saat ini lebih menonjolkan aspek kemiripan bentuk dan geometri dengan roda gigi produk original equipment manufacturer (OEM) tetapi belum diikuti dengan kajian mengenai teknologi pengerasan permukaan, teknik pengaturan kekasaran permukaan dan pengujian running-in roda gigi. Kelemahan ini menjadikan produk roda gigi UKM masih belum dapat bersaing di pasar domestik
\end{abstract}

Kata kunci: kekasaran permukaan, kekerasan permukaan, produk OEM, produk UKM, roda gigi

\section{PENDAHULUAN}

Roda gigi merupakan salah satu komponen mesin yang kompleks dalam proses perancangan dan pembuatannya sehingga dibutuhkan ketelitian dan kepresisian dalam perancangan dan proses manufakturnya [1-3]. Hingga saat ini, Usaha Kecil dan Menengah (UKM) produsen komponen otomotif di Jawa Tengah belum memproduksi roda gigi untuk sistem transmisi sepeda motor yang mampu memenuhi standar perusahaan otomotif nasional atau mampu men-supply komponen after sales di pasar komponen purna jual. Berdasarkan survei yang dilakukan di pasar purna jual di Semarang terhadap produk roda gigi transmisi sepeda motor, roda gigi transmisi yang dipasarkan merupakan produk Original Equipment Manufacturer (OEM) atau produk impor dari China dan Taiwan.

Usaha Kecil Menengah (UKM) yang akan memasok roda gigi transmisi dituntut mampu memproduksi roda gigi yang memiliki spesifikasi material, teknik manufaktur, geometri dan toleransi, pengerasan permukaan dan kekasaran permukaan yang memenuhi kualifikasi. Berdasarkan pendampingan yang telah dilaksanakan oleh Laboratorium Perancangan Teknik dan Tribologi, Jurusan Teknik Mesin UNDIP di sentra industri logam di Jawa Tengah, diketahui bahwa UKM yang memproduksi roda gigi telah mampu menghasilkan bentuk dan komposisi material yang memenuhi standar industri otomotif [4]. Untuk memperlebar kesempatan UKM masuk ke industri otomotif nasional maka Laboratorium Perancangan Teknik dan Tribologi (Lab EDT) Jurusan Teknik Mesin UNDIP mencoba membangun komunikasi dengan salah satu industri otomotif nasional. Hasilnya adalah masih terbukanya kesempatan untuk diterimanya produk roda gigi UKM jika mampu memenuhi persyaratan teknis yang diberikan oleh mereka dan memberikan harga yang kompetitif. Industri otomotif nasional juga membuka kesempatan bekerja sama melakukan pendampingan untuk menghasilkan kualitas yang lebih optimal.

Berkembangnya industri otomotif ditandai dengan naiknya produksi untuk melayani permintaan mobil dan sepeda motor setiap tahun. Jumlah permintaan mobil baru pada tahun 2001 sekitar 300 ribu unit dan meningkat hampir dua kali lipat hingga mencapai sekitar 500 ribu pada tahun 2008. Volume produksi sepeda motor pada tahun 2001 mencapai 1,5 juta unit dan meningkat pesat hingga empat kali lipat pada tahun 2008 menjadi sekitar 6 juta unit [5]. Peningkatan permintaan kendaraan baru tersebut mengakibatkan peningkatan permintaan komponen otomotif untuk perakitan, yang juga diikuti permintaan untuk penyediaan komponen suku cadang pada layanan purna jual. Pada 
komponen mobil dan sepeda motor, banyak komponen mesin yang menggunakan pasangan roda gigi untuk meneruskan daya dan mengubah sumbu putar. Jika diambil contoh untuk roda gigi transmisi sepeda motor saja, dimana jumlah produksi sepeda motor nasional pada tahun 2010 diprediksi mencapai 6,3 juta unit [6] dan harga 1 set (4 pasang) roda gigi transmisi di pasaran mencapai Rp.500.000,- maka omset untuk men-supply roda gigi transmisi mencapai Rp 3,1 Trilyun pada tahun 2010. Jika UKM mendapat share produksi sejumlah $10 \%$ dari total omset maka nilainya bisa mencapai Rp. 310 Milyar pada tahun 2010. Penelitian ini diharapkan dapat membuka jalan bagi UKM untuk dapat memasok komponen roda gigi transmisi ke pasar otomotif nasional. Selain itu, UKM juga dapat memasok ke distributor komponen sepeda motor untuk melayani komponen pada layanan purna jual.

Berdasarkan survey di UKM roda gigi yang diproduksi UKM lebih mengarah pada pesanan yang spesifik (customized) dan belum menjadi produk massal [7]. Penelitian ini mencoba mendorong UKM untuk memproduksi roda gigi yang dapat diproduksi massal dan memberikan pesasanan secara kontinyu. Pada penelitian ini, UKM produsen roda gigi di Jawa Tengah, diberikan order pembuatan roda gigi untuk sistem transmisi sepeda motor. Produk roda gigi yang dihasilkan UKM ini kemudian dianalisa dan dibandingkan dengan produk roda gigi OEM, Hasil yang dibandingkan adalah uji komposisi, nilai kekerasan dan kekasaran permukaan.

\section{BAHAN DAN PERALATAN UJI}

Roda gigi yang dianalisa dan dibandingkan pada penelitian ini adalah roda gigi produk OEM dan roda gigi produk UKM sebagaimana terlihat pada Gambar 1. Roda gigi yang dibandingkan adalah counter gear (driven gear) pada transmisi percepatan 2 sepeda motor kendaraan bebek tipe $100 \mathrm{cc}$. Bahan kedua roda gigi terbuat dari baja karbon dengan paduan rendah dimana hasil pengujian komposisi unsur yang dilakukan menggunakan alat spektrometer. Pengujian dilakukan terhadap masing-masing satu roda gigi di mana setiap roda gigi diuji komposisi sebanyak 3 kali dan hasilnya dirata-rata.

Pengujian berikutnya adalah pengujian massa dilakukan dengan timbangan dengan ketelitian $10^{-4}$ gram. Nilai kekerasan makro diuji menggunakan alat uji kekerasan metode Rockwell. Pengujian yang terakhir adalah uji kekasaran permukaan yang dilakukan menggunakan alat uji Surface Roughness Tester Mitutoyo.

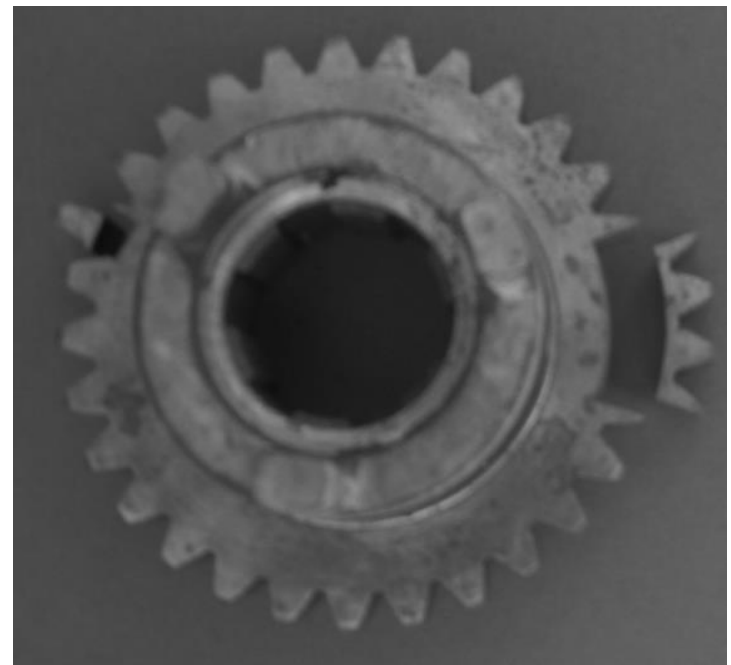

(a)

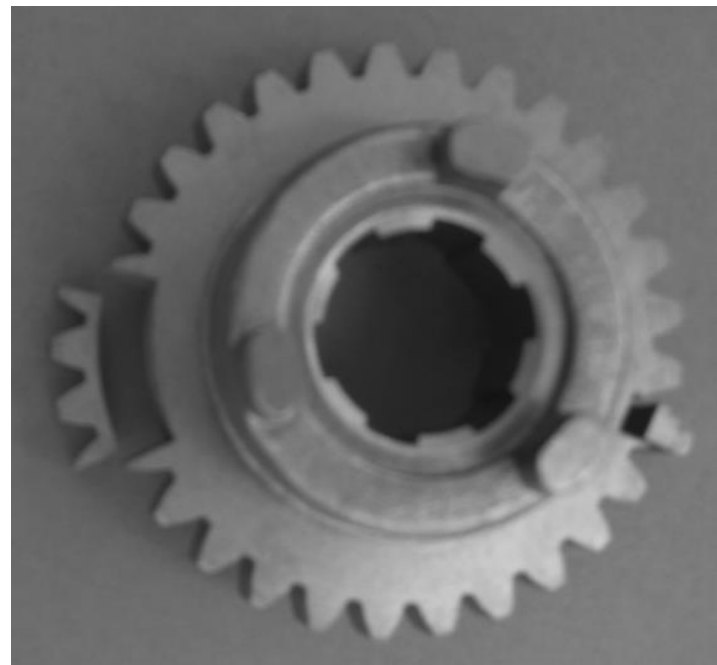

(b)

Gambar 1. (a) roda gigi produk UKM Jawa Tengah dan (b) roda gigi produk OEM

Roda gigi yang akan diuji nilai kekasaran permukaannya dipotong beberapa gigi untuk memungkinkan alat ukur kekasaran permukaan menjangkau permukaan profil involute roda gigi. Pemotongan roda gigi dilakukan menggunakan wire cutting dan hasil beberapa potongan roda gigi dapat dilihat pada Gambar 1. Hasil potongan selain digunakan untuk uji kekasaran permukaan juga nantinya akan digunakan untuk penelitian lanjutan pada observasi struktur mikro yang akan dibahas pada paper yang lain.

\section{HASIL DAN PEMBAHASAN}

Sub-bab ini menyajikan pembahasan pada hasil pengujian komposisi unsur, massa roda gigi, kekerasan makro roda gigi dan kekasaran permukaan roda gigi. Produk UKM dibandingkan dengan produk OEM.

\subsection{Komposisi kimia}

Hasil pengujian komposisi unsur roda gigi produk UKM dan produk OEM dapat dilihat pada Tabel 1. Komposisi unsur kimia yang dominan adalah Fe dengan kandungan di atas $96 \%$ dan akdar karbon berkisar 0,4\%. Unsur yang memiliki komposisi yang cukup tinggi adalah Krom dan Mangan yan masing-masing memiliki kandungan berkisar 
Rifky Ismail, Perbandingan Produk Roda Gigi Ukm Dan Roda Gigi Original Equipment Manufacturer (Oem) Untuk Produk Roda Gigi Transmisi Sepeda Motor

antara $1 \%$ dan 0,7-0,8 persen untuk roda gigi UKM dan OEM. Secara komparatif, hasil pengujian unsur ini menunjukkan bahwa UKM telah mampu menghasilkan komposisi unsur kimia yang mendekati roda gigi produk OEM. Perbedaan unsur kimia antara kedua jenis roda gigi ini tidaklah signifikan. Kesamaan unsur ini dapat dicapai oleh UKM karena UKM terlebih dahulu mendapatkan data pengujian komposisi unsur roda gigi produk OEM kemudian melakukan proses casting untuk mendapatkan material awal roda gigi produk UKM.

Tabel 1. Hasil pengujian komposisi unsur roda gigi produk UKM dan OEM menggunakan spektrometer

\begin{tabular}{ccccccccccc}
\hline $\begin{array}{c}\text { Jenis } \\
\text { Roda Gigi }\end{array}$ & Fe & $\mathbf{C}$ & $\mathbf{S i}$ & $\mathbf{M n}$ & $\mathbf{P}$ & $\mathbf{S}$ & $\mathbf{C r}$ & $\mathbf{M o}$ & $\mathbf{N i}$ & $\mathbf{A l}$ \\
\hline UKM & 96,9 & 0,409 & 0,25 & 0,771 & 0,0089 & 0,0217 & 1,03 & 0,153 & 0,129 & 0,0324 \\
OEM & 97 & 0,44 & 0,284 & 0,812 & $<0.0050$ & 0,0175 & 1,07 & 0,17 & 0,0426 & 0,045 \\
\hline
\end{tabular}

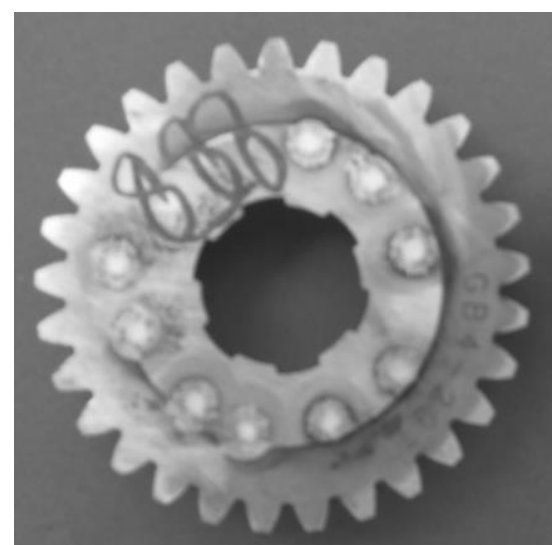

Gambar 2. Roda gigi produk OEM yang telah mengalami pengujian komposisi unsur

\subsection{Massa}

Tabel 2 menunjukkan hasil pengukuran massa spesimen untuk kedua produk. Pengukuran massa dilakukan secara berulang dan hasil rata-ratanya ditampilkan pada tabel ini. Terdapat tiga buah produk roda gigi yang diuji massanya dan dibandingkan. Hasilnya roda gigi OEM menunjukkan tidak adanya perbedaan yang signifikan terhadap massanya sedangkankan roda gigi UKM menunjukkan massa yang menunjukkan perbedaan. Perbedaan terbesar adalah massa roda gigi kedua terhadap roda gigi ketiga yang berbeda mencapai 14 persen massa. Roda gigi produk UKM dibuat melalui proses casting yang kemudian dihaluskan dengan proses machining. Proses casting dapat memberikan perbedaan massa apabila terdapat porositas pada proses pengecorannya. Kurangnya kepresisian massa ini menjadi catatan perbaikan yang harus dilakukan oleh UKM.

Tabel 2. Pengukuran massa tiga buah roda gigi produk UKM dan OEM.

\begin{tabular}{cccc}
\hline Jenis Roda Gigi & Roda Gigi 1 (gr) & Roda Gigi 2 (gr) & Roda Gigi 3 (gr) \\
\hline UKM & 165,043 & 142,670 & 163,342 \\
OEM & 171,834 & 171,476 & 171,996 \\
\hline
\end{tabular}

\subsection{Pengujian kekerasan makro}

Hasil pengujian kekerasan makro yang dilakukan pada beberapa titik uji pada bagian kepala dan akar gigi dapat dilihat pada Tabel 3 dan Tabel 4. Pada pengujian kekerasan kepala gigi sebagaimana terlihat pada Tabel 3, titik pengujian pada kepala gigi berjumlah 4 titik pengujian dengan titik uji pertama mendekati permukaan kepala gigi dan selanjutnya merupakan fungsi kedalaman.Titik uji 4 adalah titik terjauh dari permukaan. Hasil pengujian menunjukkan bahwa roda gigi UKM dan OEM memiliki nilai kekerasan makro kepala gigi yang hampir serupa, sekitar 52 - 56 HRC. Tidak ada perbedaan signifikan pada pengujian titik uji pertama hingga keempat.

Pengujian kekerasan pada akar gigi dilakukan terhadap 2 titik uji yang berlokasi pada pengujian bagian dalam akar gigi sebagaimana terlihat pada Tabel 4. Hasil pengujian menunjukkan bahwa roda gigi UKM tidak memiliki perbedaan pada nilai kekerasan akar gigi dan kepala gigi, yaitu berkisar $56-57 \mathrm{HRC}$. Hal ini berbeda dengan roda gigi produk OEM yang memiliki nilai kekerasan akar gigi yang lebih rendah, 41 - 48 HRC. Secara teori, roda gigi dituntut untuk memiliki permukaan yang lebih keras dibandingkan dengan akar gigi karena permukaan gigi menerima beban kontak dan gesekan [8]. Permukaan yang lebih keras akan menjaga permukaan kontak roda gigi memiliki umur pakai yang lebih panjang dibandingkan dengan permukaan yang lunak. 
Bagian dalam roda gigi mengalami beban puntir sehingga membutuhkan ketangguhan yang lebih tinggi dan material yang lebih ulet [9-10]. Kekerasan yang tinggi mengakibatkan menurunnya nilai ketangguhan bagian dalam roda gigi. Hal ini menunjukkan bahwa UKM membutuhkan pengembangan teknik pengerasan permukaan roda gigi untuk memberikan pengerasan pada permukaan dan menjaga bagian dalam roda gigi tetap ulet.

Tabel 3. Pengukuran nilai kekerasan makro roda gigi produk UKM dan OEM pada kepala roda gigi

\begin{tabular}{ccccc} 
Jenis Roda Gigi & $\begin{array}{c}\text { Titik Uji 1 } \\
\text { (HRC) }\end{array}$ & $\begin{array}{c}\text { Titik Uji 2 } \\
\text { (HRC) }\end{array}$ & $\begin{array}{c}\text { Titik Uji 3 } \\
\text { (HRC) }\end{array}$ & $\begin{array}{c}\text { Titik Uji 4 } \\
\text { (HRC) }\end{array}$ \\
\hline UKM & 54 & 56,5 & 57 & 56 \\
OEM & 53 & 53,5 & 54 & 52 \\
\hline
\end{tabular}

Tabel 4. Pengukuran nilai kekerasan makro roda gigi produk UKM dan OEM pada akar roda gigi

\begin{tabular}{ccc} 
Jenis Roda Gigi & Titik Uji 1 (HRC) & Titik Uji 2 (HRC) \\
UKM & 57 & 56 \\
OEM & 48,5 & 41,2 \\
\hline
\end{tabular}

\subsection{Pengujian kekasaran permukaan}

Pada roda gigi UKM dan OEM, pengujian kekasaran permukaan dilakukan pada tiga gigi yang berbeda pada satu roda gigi. Pengujian kekasaran permukaan dinyatakan menggunakan kekasaran permukaan rata-rata absolut (Ra) dan rata-rata akar kuadratik $(\mathrm{Rq})$. Ketiga hasil pengukuran roda gigi produk UKM menunjukkan nilai kekasaran permukaan yang sangat tinggi. Pada pengukuran Ra menunjukkan nilai kekasaran berkisar antara 1,7 - 2,4 mikrometer jauh lebih besar dibandingkan dengan nilai kekasaran permukaan roda gigi produk OEM yang berkisar antara 0,7 mikrometer. Demikian juga nilai kekasaran akar kuadratik (Rq) produk UKM yang berkisar antara 2,1 - 3,1 mikrometer.

Kekurangan produk UKM yang didapatkan pada pengukuran kekasaran permukaan ini yang pertama adalah tidak konsistennya nilai kekasaran permukaan antara satu gigi dengan gigi yang lain pada satu roda gigi dan yang kedua adalah tingginya nilai kekasaran permukaan dibandingkan dengan produk OEM. Nilai kekasaran permukaan yang tinggi dapat mengakibatkan roda gigi yang menghasilkan suara yang berisik, tekanan kontak yang tinggi pada permukaan, naiknya temperatur kontak dan dapat mengakibatkan keausan yang berlebih. Hal ini membutuhkan penanganan yang baik agar roda gigi produk UKM mampu memiliki nilai kekasaran yang lebih rendah dan lebih seragam pada setiap giginya.

Tabel 3. Pengukuran nilai kekerasan makro roda gigi produk UKM dan OEM pada kepala roda gigi

\begin{tabular}{ccccccc}
\hline Jenis Roda Gigi & $\begin{array}{c}\text { Pengujian } \\
\text { Gigi 1 } \\
\left(\mathbf{R}_{\mathbf{a}}\right)\end{array}$ & $\begin{array}{c}\text { Pengujian } \\
\text { Gigi 1 } \\
\left(\mathbf{R}_{\mathbf{q}}\right)\end{array}$ & $\begin{array}{c}\text { Pengujian } \\
\text { Gigi 2 } \\
\left(\mathbf{R}_{\mathbf{a}}\right)\end{array}$ & $\begin{array}{c}\text { Pengujian } \\
\text { Gigi 2 } \\
\left(\mathbf{R}_{\mathbf{q}}\right)\end{array}$ & $\begin{array}{c}\text { Pengujian } \\
\text { Gigi 3 } \\
\left(\mathbf{R}_{\mathbf{a}}\right)\end{array}$ & $\begin{array}{c}\text { Pengujian } \\
\text { Gigi 3 } \\
\left(\mathbf{R}_{\mathbf{q}}\right)\end{array}$ \\
\hline UKM & 1,667 & 2,178 & 2,439 & 3,103 & 2,09 & 2,717 \\
OEM & 0,763 & 0,991 & 0,741 & 0,926 & 0,706 & 0,91 \\
\hline
\end{tabular}

\section{PENINGKATAN KUALITAS RODA GIGI UKM}

Berdasarkan observasi komposisi, massa, kekerasan dan kekasaran roda gigi memiliki kualitas yang baik pada pengujian komposisi unsur tetapi menunjukkan kelemahan pada pengujian massa, kekerasan dan kekasaran permukaan. Untuk mengatasi hal tersebut, diusulkan beberapa solusi perbaikan yang diharapkan dapat meningkatkan kualitas roda gigi produk UKM.

Yang pertama untuk mengatasi kekurangan dari sisi massa. Pada kasus penelitian ini, roda gigi UKM dibuat dengan cara dicasting terlebih dahulu kemudian dilakukan proses permesinan untuk menghasilkan bentuk profil gigi sesuai dengan produk OEM. Proses casting yang kurang baik akan memberikan dampak adanya porositas pada bagian dalam roda gigi yang mengakibatkan berkurangnya massa produk roda gigi UKM. Untuk mengurangi perbedaan massa roda gigi maka proses manufaktur roda gigi menggunakan material awal berupa silinder pejal yang dibeli secara komersial. Material pejal yang dipasarkan secara komersial diproses menggunakan pembentukan dingin dan panas yang menghasilkan struktur yang lebih solid. Material pejal dapat dibeli yang komposisinya mendekati dengan produk roda gigi OEM seperti material silinder pejal AISI 4140. Material ini kemudian dibentuk menjadi roda gigi menggunakan proses yang sama dengan proses yang dilakukan oleh UKM.

Yang kedua untuk memperbaiki kualitas pengerasan pada roda gigi. Selama ini UKM mengeraskan roda gigi menggunakan 2 metode konvensional yaitu perlakuan panas di dalam tungku peleburan dan perlakuan panas menggunakan nyala api bersumber dari pembakaran oksi asitilen atau bahan bakar lainnya. Gambar 3(a) menunjukkan pemanasan yang dilakukan oleh UKM dalam penelitian ini, menggunakan tungku peleburan yang biasanya digunakan 
Rifky Ismail, Perbandingan Produk Roda Gigi Ukm Dan Roda Gigi Original Equipment Manufacturer (Oem) Untuk Produk Roda Gigi Transmisi Sepeda Motor

untuk melebur alumunium. Pada beberasa survey yang dilakukan pada UKM yang lebih besar, perlakuan panas roda gigi oleh UKM telah menggunakan dapur pemanas seperti pada Gambar 3(b).

Upaya untuk menghasilkan pengerasan permukaan yang lebih baik dapat dilakukan menggunakan alat pemanas induksi seperti pada Gambar 4. Laboratorium Perancangan Teknik dan Tribologi, Jurusan Teknik Mesin UNDIP telah menggunakan alat pemanas induksi untuk pengerasan permukaan dan memberikan hasil yang memuaskan. Metode dan teknik ini dapat diimplementasikan untuk mengeraskan roda gigi dengan hasil yang lebih seragam, waktu yang lebih cepat dan menjaga bagian dalam roda gigi untuk tetap ulet [11-12]. Penelitian sebelumnya menggunakan kajian numerik menunjukkan bahwa lapisan tipis yang keras dapat mengurangi distribusi tegangan pada permukaan kontak [13].

Yang ketiga untuk mengurangi kekasaran permukaan pada roda gigi perlu dilakukan proses grinding saat finishing proses manufaktur roda gigi. Pada penelitian ini, saat pengamatan dilakukan UKM tidak melakukan proses penghalusan permukaan. Roda gigi hanya dilakukan proses permesinan kemudian dilakukan proses pengerasan. Tidak adanya proses grinding ini menjadikan nilai kekasaran permukaan roda gigi menjadi sangat tinggi. Upaya grinding dapat dilakukan sebagaimana terlihat pada Gambar 5.

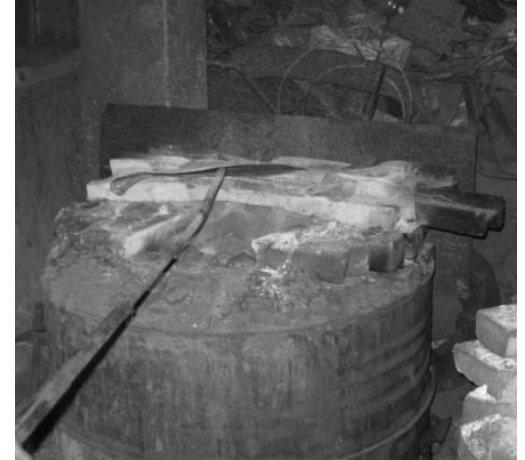

(a)

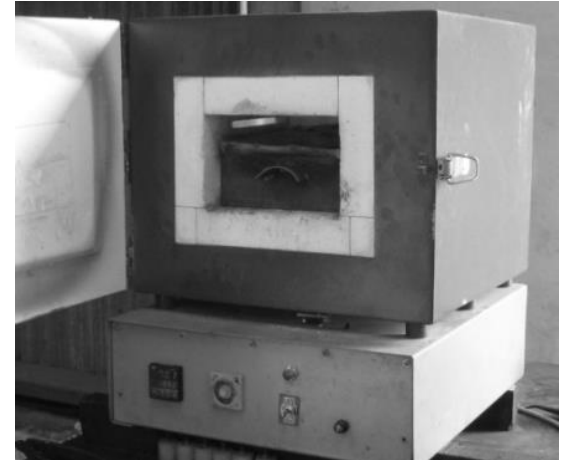

(b)

Gambar 3. (a) Dapur peleburan alumunium yang digunakan untuk perlakuan panas dan (b) tungku/dapur pemanas yang didesain sendiri yang digunakan untuk perlakuan panas roda gigi.

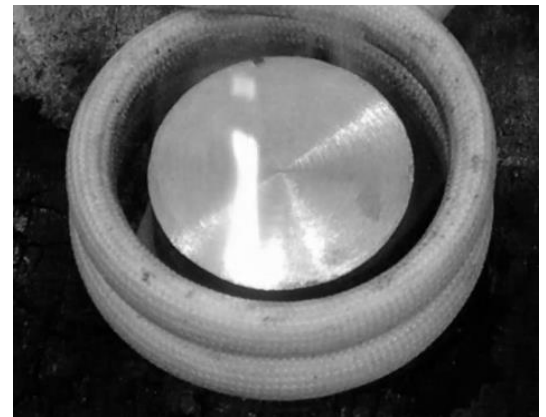

(a)

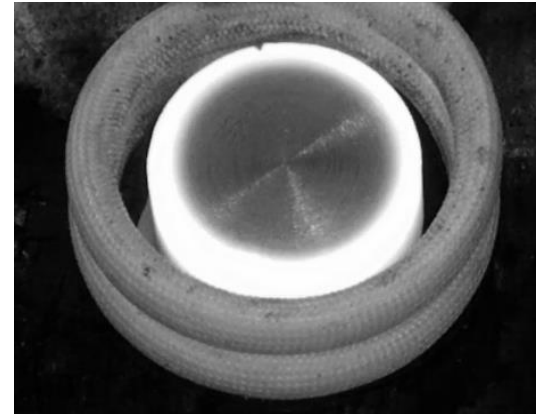

(b)

Gambar 4. (a) Spesimen disiapkan untuk dipanaskan dalam koil induksi dan (b) permukaan spesimen yang mencapai 900 Celsius dalam waktu kurang dari 20 detik [11].

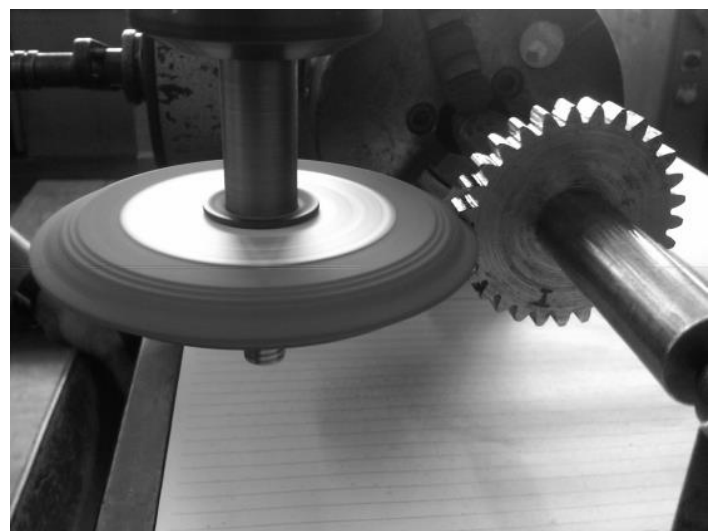

Gambar 5. Penghalusan permukaan roda gigi menggunakan batu gerinda yang dibentuk profil roda gigi gigi. Penghalusan dilakuan pada setiap celah roda gigi untuk menghilangkan bekas permesinan yang tertinggal. 
Grinding atau proses gerinda permukaan roda gigi diantaranya dapat dilakukan menggunakan metode single grinding process dimana sebuah gerinda diputar pada setiap celah antar gigi dalam sebuah roda gigi. Parameter yang berpengaruh pada proses ini adalah ketepatan posisi permukaan gerinda terhadap celah roda gigi, kecepatan putar gerinda dan waktu proses gerinda. Hal ini membutuhkan penelitian lebih lanjut untuk mendapatkan parameter terbaik pada penghalusan permukaan roda gigi.

\section{KESIMPULAN}

Penelitian ini dilaksanakan untuk membandingkan beberapa parameter uji pada roda gigi produk UKM di Jawa Tengah dan roda gigi produk OEM untuk sistem transmisi sepeda motor bebek tipe C100. Kajian perbandingan ini dilakukan untuk mengamati kekurangan produk UKM yang hingga saat ini masih belum mampu menembus pasar otomotif nasional, baik untuk pasar pabrikan maupun untuk pasar purna jual. Penelitian ini membandingkan komposisi unsur roda gigi, massa roda gigi, kekerasan makro roda gigi dan kekasaran permukaan roda gigi. Berdasarkan observasi yang telah dilakukan, roda gigi memiliki kualitas yang baik pada pengujian komposisi unsur tetapi menunjukkan kelemahan pada pengujian massa, kekerasan dan kekasaran permukaan. Untuk mengatasi hal tersebut, diusulkan beberapa solusi perbaikan yang diharapkan dapat meningkatkan kualitas roda gigi produk UKM. Diantaranya proses manufaktur menggunakan material solid yang tersedia di pasar, penggunaan pemanas induksi untuk pengerasan permukaan dan penggunaan metode gerinda untuk penghalusan permukaan.

\section{REFERENSI}

[1] Niemann, G., 1960, Machine Element Vol II: Gears Design and Calculation in Mechanical Engineering, Springer Verlag, Berlin, Jerman.

[2] Shigley, J.E., 1983, Mechanical Engineering Design, Mc Graw Hill, Michigan, USA.

[3] Maitra, G.M., 1989, Handbook of Gear Design, McGraw-Hill Publishing Company Limited, New Delhi, India.

[4] Ismail, R., dkk., 2009, "Penyuluhan Peningkatan Daya Saing Produk Industri Kecil dan Menengah (IKM) di Sentra Industri Kecamatan Juwana, Kabupaten Pati, Jawa Tengah,” Laporan Pengabdian kepada Masyarakat Jurusan Teknik Mesin UNDIP.

[5] Departemen Perdagangan Indonesia, 2007, "Commodity Profile Series - Indonesia Automotive Component. A Trade Research Publication of The Trade Research and Development Agency," Laporan Departemen Perdagangan Indonesia.

[6] Zulkifli, B.J., 2010, "Penjualan Nasional Sepeda Motor akan Mencapai Rp. 65 Trilyun," http://www.otomotif.kompas.com/, diakses pada 20 November 2013.

[7] Ismail, R., dkk., 2010, "Optimasi dan Efisiensi Proses Produksi di UKM Klaster Komponen Otomotif di Juwana," Laporan Pengabdian kepada Masyarakat Jurusan Teknik Mesin UNDIP.

[8] Kalpakjian, S., Schmid, S., 2007, Manufacturing Processes for Engineering Materials, Prentice Hall, New Jersey.

[9] Rakhit, A.K., 2000, Heat Treatment of Gears: A Practical Guide for Engineers," ASM International Press Materials Park, Ohio, USA.

[10] Rudnev, V. Loveless D. dan Cook, R., 2003, Handbook of Induction Heating, Marcel Decker, Inc, NY, USA.

[11] Ismail, R., Prasetyo, D.I., Tauviqirrahman, M., Yohana E., Bayuseno, A.P., 2014, "Induction Hardening of Carbon Steel Material: The Effect of Specimen Diameter," Advanced Materials Research, 911: 210-214.

[12] Ismail, R., Tauviqirrahman, M., Bayuseno, A.P., Sugiyanto Jamari, 2013, "Pemanfaatan Alat Pemanas Induksi untuk Industri Kecil dan Menengah,” Prosiding Seminar Nasional Teknik Mesin dan Teknologi Kejuruan, UNJ Jakarta.

[13] Ismail, R., Tauviqirrahman, Jamari, Schipper, D.J. "Finite Element Analysis of Sliding Contact of A Hard Cylinder on A Layered Elastic-Plastic Solid," Proceedings of International Conference on Advances Mechanical Engineering (ICAME), Shah Alam, Malaysia, 2009. 